\title{
Evolution of Pharmacy in Karnataka: A Bird View
}

\author{
Kempaiah Suresh* and V. Balamuralidhara \\ Department of Pharmaceutics, JSS College of Pharmacy, JSS University, Sri Shivarathreeshwara Nagara, \\ Mysore - 570015, Karnataka, India; kempaiahsuresh@gmail.com
}

\begin{abstract}
In India, Pharmacy profession ensures the quality drugs are made available at affordable prices to the people. Drugs Regulation in India is implemented under the provisions of formerly called The Drugs Act, 1940 and Rules 1945 until the Drugs and Cosmetics Act, 1940 came to existence and Regulatory reforms efforts in country initiated with Mashelakar Committee observation. Karnataka has been one of the pioneer States in India with an exemplary track record. With its rich tradition and ethical values embedded in the pharmacy profession, the important milestones recorded depict the history and development of pharmacy profession and educational activity in Karnataka. It has a strong base of educational institutions imparting courses in Pharmacy and some of the institutions have international repute to its credit. Karnataka is one of the fastest growing states in the Country and nearly 268 pharmaceutical and biotech companies are housed in the State. Karnataka is a vibrant pharmaceutical manufacturing hub fortified with sound knowledge based institutions and skilled human resource available in the state; it provides innovative, quality and affordable health care solution to masses. In this short review author provides some of the glimpses of the pharmacy profession in Karnataka.
\end{abstract}

Keywords: Drug, Education, Health, Karnataka, Regulation

\section{Introduction}

The Indian Pharma Industry was almost nonexistent in 1980. But now Indian pharma industry is on the verge of becoming a major global market by 2020 . It is estimated to be worth about 4.5 billion. India ranks $3^{\text {rd }}$ in the world terms of volume and $14^{\text {th }}$ in terms of value. Approximately $70 \%$ of the patients in developing countries receive Indian medicines through NGOs. The Drugs and Cosmetics Act, (D\&C Act) 1940 regulates the Pharma Industry and distribution. Central Drugs Standard Control Organization (CDSCO), Ministry of Health and Family Welfare, Government of India provides general information about drug regulatory requirements in India. Karnataka boasts of its pharma industry for providing high quality medicines on par with international standards. With a small number of
263 manufacturing units including Drugs and Medical Devices, $8 \%$ of exports of the country are contributed by Karnataka and as good number of leading brands are manufactured in Karnataka. Drugs manufactured in Karnataka are exported to 206 countries.

Drug is the only commodity which cannot be compromised for any reason. Hence the need for an efficient Drugs Control Administration, to supervise the quality, availability at affordable price of drugs plays a pivotal role. The Government of India enacted the "Drugs Act" in 1940 to regulate the import, manufacture, distribution and sale of drugs and received the ascent of the Governor General on $10^{\text {th }}$ April 1940. The Drugs Rules were framed during 1945 to give effect to the provisions of the Act. In the year 1962, Cosmetics were brought under the purview of enforcement and then onwards the Act has been titled as "The Drugs and Cosmetics Act". India

${ }^{*}$ Author for correspondence 
being a federal country, regulatory competence for drug regulation is shared between the centre and the states. The study of administrative structure and functioning of drug regulatory authorities at centre and states levels in India focussing on functioning of Central Drugs Standard Control Organization (CDSCO), the national level regulators, and State Drugs Regulatory Authorities (SDRAs) in India which are governed by the Drugs and Cosmetics Act, 1940. Examining the amount and the scale of the regulatory challenges facing the administrative structures and functioning of state drug regulatory authorities in India. Drugs and Cosmetics Act, 1940 and Rules 1945 recognizes mainly three Functionaries to implement the provisions of the Act and Rules-

The primary research study includes challenges confronting the current state drug regulatory system. The research was carried by stakeholder interviews and information gathered through RTI applications and Department websites. Although the Drugs and Cosmetics Act, 1940 (hereafter referred as DCA) is country legislation, the state and central have been divided on the control over the implementation of DCA. The main purpose of this study is to the various kinds of regulatory works and pharmacy related developments existing in Karnataka. In this Karnataka state one of the most important state of India was selected based on their overall development in pharmacy, Functional activities, Duties and administrative structure at enforcement and Drugs testing.

\section{History}

Drugs Control Department in Mysore came into existence prior to reorganization of the states. Drugs Inspectors, two from Bombay Karnataka Area, One from Madras province and one deputed from the Central Drugs Control Directorate in the Directorate of Health Services. The Director of Health was designated as the First Drugs Controller of the Mysore State. After reorganization of the States all the officers opted for Mysore State Cadre and thus the Department was established and started implementing. With the change in name of the State from Mysore to Karnataka, the Department also made known as Karnataka Drugs Control Department. It is worth mentioning here that this is the only Department located within the reach of the Administrative Power House -Vidhana Soudha, The credit should go to Late K. N. Shanbhogue, the first Drugs Controller for convincing the then Government headed by Sri. S. Nijalingappa as Chief Minister and Late Dr. K. Nagappa Alva, the then Health Minister.

The Government wanted to make the Drugs Inspector post gazetted post, throughout India, since the it was planning to implement the Drugs and Magic Remedies Act 1954 in India and wherein only gazetted officer are empowered to implement it.

Sri S. K. Borkar committee made a detailed observation in their report suggested setting up of independent Drug Control Administrations in all States, staffing pattern and to establish the Drug Testing facilities. These made a big impact on the states to be more stringent and to enforce the provisions of DCA and Rules, 1945 effectively in the whole country.

Until $1^{\text {st }}$ November 1988 the Head of the Department Controller was the authority for issue of licenses to manufacture and Distribution of Sale of Drugs.

The district controllers were authorized and designated Authorities and with this change the system of issue of licenses to retail and wholesale licensing. Licenses were granted by the district licensing Authority. And At present there are 36 circles for issue of licenses to Retail and wholesale units and circle is headed by Assistant Drugs Controller who is functioning as "Licensing Authority" with delegated powers under the Act. At present the Head of Department and Controller is the Authorized for entire State but he has delegated his powers to All Assistant Drugs Controllers with the approval of State Government ${ }^{1,2}$.

\section{Drugs Control Administration and its Hierarchy}

The Drugs Control Administration are broadly classified into two wings Central and State Government level.

\subsection{The Central Drug Agency}

It is controlled by the central Government and concerned in policy and making of laws and rules and management of committee (Law Making Bodies). Licensing not covered by the state. Any new drug to be sold in the country and new trial for the drug.

\subsection{The State Drugs Control Agency}

Licensing is granted for drug and cosmetic manufacturing and Retail and wholesale units. It has a clear mandate to 
ensure manufacture and distribution of standard drugs at the prices affordable to the consumers at large and to implement the provisions of the rules framed by National Pharmaceutical Pricing Authority (NPPA) from time to time.

Drugs Control Administration in Karnataka is under the administrative control of Ministry of Health and Family welfare in the Government of Karnataka. The Drugs Controller who will be reporting to Government.

\section{Role of Drugs Control Department}

The following acts are implemented in the state of Karnataka:

- DCA

- Magic Remedies (Objectionable Advertisements) Act 1954 and Rules 1955

- The NDPS Act, 1985 and Rules, 1985

- The Drugs Price (Control) Order, 1995

\section{The Department since the Inception in 1965 and has Three Divisions}

1. Implementation DCA by Inspectors

2. Testing Wing for drugs and cosmetics

3. Pharmacy education:

Government College of Pharmacy, Bangalore conduct

Examining authority headed by secretary to regulate pharmacy at Diploma level.

\subsection{Law Enforcement Wing}

Implementation of Drugs and Cosmetics Act 1940 under which grant and renewal of Licenses for manufacturing and Sales units, Blood banks and Medical Devices. Legal samples of Drugs and cosmetics are drawn for analysis, complaints investigation, prosecute the offenders etc.

It functions in Two-tier system

- Main Head office

- Divisional Circle offices
And Level of Officers is:

- Controller for the State of Karnataka and Controlling Authority

- Addl. Drugs Controller for the state of Karnataka

- Deputy Drugs Controller for Regional and Head office (DDC)

- Asst. Drugs Controller are Divisional Licensing Authority (ADC)

- Drugs Inspector is the Inspecting authority (Section 21 Notified) (DI)

\subsubsection{Main Functions Head Quarters}

- Karnataka state administration. The manufacturing Licenses grant and renewing of English medicines Blood, Blood Products, Medical Devices, to grant and renew licenses for Retail and wholesale firms also gives approval for Public Testing Laboratory and Blood Storage Centers, It also grant Quota of NDPS. Investigate complaints received from public and once in a year inspections of manufacturing and selling Units, drawing legal sample of drugs and cosmetics. To launch prosecution against the offenders. The department also issues certificates to firm like GMP WHO, No conviction, Freesale, Market Standing and others.

\subsubsection{Regional Offices Functions}

Entire Karnataka has been divided to 11 divisional Offices under the administrative control Regional controllers are Located at Head Quarters, Belgaum, Davanagere, South Karnataka, Dharwad, Bellary, Tumkur, Mangalore and Kalbugi. The main function are the overall administration and supervision of Circles, gathering of information, drawing of samples, carry out inspection of sale unit and blood banks, complaints investigation. One Inspector is working as Intelligence Officer.

\subsubsection{Circle Offices}

Karnataka is having 30 districts and each district is having circle office and the district like that of Mysore, Kalburgi, Bellary and Dharwad etc., which is having additional circle offices and Bangalore city has six circles offices with additional $6 \mathrm{ADC}$, under whom inspecting authority are working. Drugs controller have decentralized the power to 
ADC under DCA. ADC functions includes head of office and jurisdictional administration is under his control grant and Renewal of sales units, Blood banks and storage center, legal will be drawn from government hospital and sale unit for quality check, complaints investigations and launching prosecutions against offenders.

\section{Drugs Testing Laboratory}

The Drugs Testing Laboratory statuary Laboratory located at Main Building of Drugs Control Department Bengaluru. The Drugs Controller is the administrative head of the Lab. The Principal Scientific officer is the head of Drugs Testing Laboratory. The lab carries out the test and analysis of Drugs and cosmetics sent by the enforcement officer from their jurisdiction. The Lab has no facility for vaccines and Sera. They also have animal house facilities approved by the Central Government.

The two new laboratories was established in 2008

- Divisional Drug Testing Laboratory, Hubballi.

- Divisional Drug Testing Laboratory, Bellary.

The Laboratory's is headed by Principal Scientific officer. The chief Scientific Officer is heading the laboratory at Bengaluru, Habballi and Bellary. The laboratory is divided different sections which are headed by scientific officers. The Junior Scientific Officer and Supporting staff (Technical and Non-Technical) analyses the samples and forward the report to Scientific Officers they are notified as Government Analyst. Pharmacy Education: Government College of Pharmacy, Bangalore conduct courses and conduct examination for the students. Principal Government College of pharmacy is the chairman for conduct of Diploma examinations and DDC as Secretary. There about 95 colleges in Karnataka State.

Retail and Wholesale Units: There are about 22851 retail and 7730 wholesale and 515 restricted license holders in Karnataka (Figure 1). The department has launched a web site which enables public for applying online sales License and Licenses are also granted online in the State of Karnataka.

All the Licensee will get the message alert in form message to their mobile numbers in case of any drug declared as not of standard quality by the Drugs Testing Labs in Karnataka.
The Services related to Sale are under SAKALA services and time bound services are rendered to the public and Licensee $e^{4,5}$.

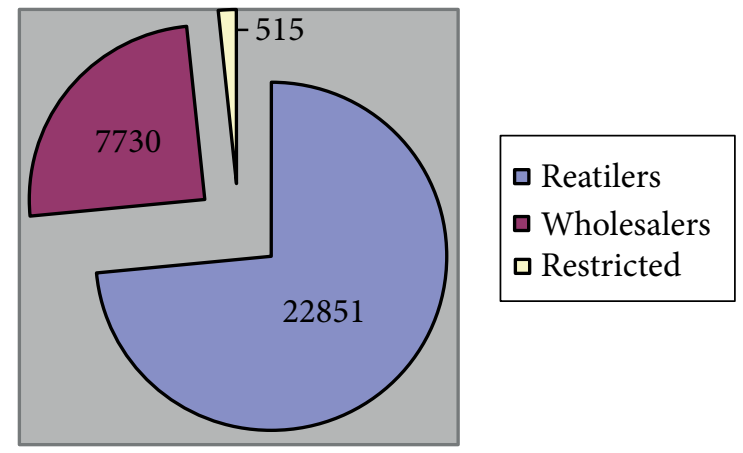

Figure 1. Sales Licenses in Karnataka.

\section{Karnataka Pharmaceutical Industry}

Karnataka boasts of its pharmaceutical industry for providing high quality medicines on par with international standards. With a small number of 263 manufacturing units including Drugs and Medical Devices, $8 \%$ of exports of the country are contributed by Karnataka and as good number of leading brands are manufactured in Karnataka. Drugs manufactured in Karnataka are exported to 206 countries.

Leading pharma brands which are manufactured in Karnataka

- Crocin tablets and syrup

- Calpol Drops

- Becosules Capsules

- Augmentin tablets and syrup

- Voveran Tablets

- Benadryl Syrup

- Disprin Tablets

- Zental Suspension

- Beplex Forte

- Corex Cough Syrup

- Listrine Mouth Wash

- Ecosprin Tablets

- Nizral Solution

- Nervit

Some of the Leading companies are as Micro Labs, Cipla, Strides, Biozen, Kemwell Biopharma Ltd., Medreich, Mylan, Vascular Concept for Medical devices, Ranbaxy 
(Vaccines) Jubiliant Life Sciences, Astra Zeneca Pharma India, Bioneeds-approved lab for Animal Testing 82 units are WHO GMP Certified and 8 are FDA Approved Plants and several units are TGA, MHRA approved. Except Suppostaries \& pessaries all type of formulation are manufactured in Karnataka. There are 194 Blood Banks and 175 Blood Storage centre across Karnataka (Figure 2). The department has launched a web site which enables public in searching for blood across all blood banks in the State of Karnataka ${ }^{6}$.

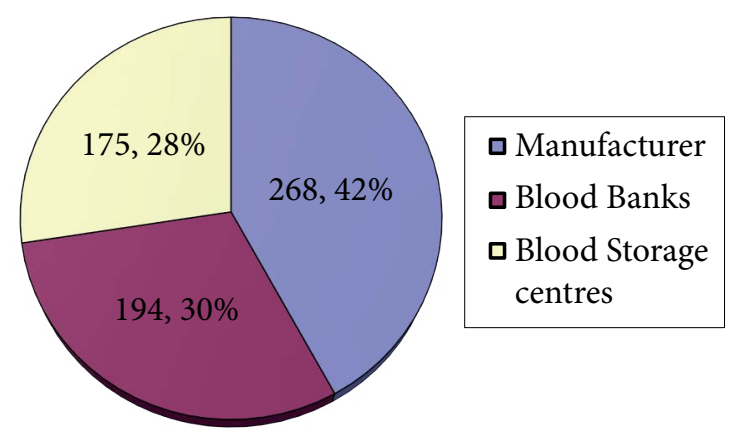

Figure 2. Manufacturing licenses in Karnataka.

\section{Pharmacy Council of State}

The state pharmacy council was earlier called as Mysore State Pharmacy Council. It was functioning from the Drugs Controller office. The then Drugs Controller was the first president of council. Karnataka state pharmacy council has registered more than fifty thousand pharmacist in his Register. They also regulate pharmacy practice in the state of Karnataka ${ }^{7}$.

\section{Acknowledgement}

I would like to thank Sri Venkatesh Assistant Drugs Controller Drugs control Administration and Sri Gundu Rao for providing support to make this manuscript in the best mode form.

\section{Conflicts of Interest}

The Author declares that there are no conflicts of interest.

\section{Conclusion}

The pharmacy education in Karnataka has witnessed tremendous expansion in last one decadeRegulatory responsibilities are divided into central the national level regulators, and State Authorities. Both the state and Central are entitled to implement the Act, but the division has created the risk of fragmentation. There is no interaction and coordination between central and states (Granting of fixed dose combination by state Licensing Authorities). In some of the Regulated countries (China) the all the applications are first approved by the local authorities then Central Drug Authority is the Approving Authority. There is lacuna in pay, work conditions facilities and training. The physical structure of state laboratories needs to be more accountable. E-Licensing digital database with good investment and expansion facilities to be provided at state Level. The entire spectrum of the pharmacy related activities in Karnataka are brought under one roof. From the origin of pharmacy education, drugs control administration, pharmaceutical Industry and trade business establishment to all around development of pharmacy in Karnataka from the inception of it.

\section{References}

1. National Health Policy; 2015. Available from: www.moh. fw.nic.in

2. Singh H, Prakashan V. History of Pharmacy in IndiaPharmacy Practice; 2002. p. 226. Available from: www.iisc. ernet.in/currsci/jul252002/171

3. History of Pharmacy. Available from: www.kar.nic.in

4. A brief note on Drugs Control Department Karnataka. Available from: www.kar.nic.in

5. A brief history of CDSCO. Available from: www.cdsco.nic. in

6. Ladkat SR, Khodade RK, Chaudhari P, Kasture PV. The Indian pharmaceutical industry: Evolution of regulatory system and present scenario. International Research Journal of Pharmacy. 2012; 3(6). Available from: www. irjponline.com

7. Information on Karnataka state pharmacy council. Available from: www.kspc.nic.in 